\title{
Initial events in bovine coronavirus infection: analysis through immunogold probes and lysosomotropic inhibitors
}

\author{
H. R. Payne ${ }^{1}$, J. Storz ${ }^{1}$, and W. G. Henk ${ }^{2}$ \\ Departments of ${ }^{1}$ Veterinary Microbiology and Parasitology and of ${ }^{2}$ Veterinary Anatomy \\ and Fine Structure, Louisiana State University, Baton Rouge, Louisiana, U.S.A.
}

Accepted May 14, 1990

Summary. The early events in the infection of human rectal tumor cells by bovine coronavirus were investigated by colloidal gold-mediated immunoelectron microscopy and by analysis of the effect of lysosomotropic weak bases on virus yield. Electron microscopic studies revealed sites of fusion between the virus envelope and the plasmalemma but fusion events along intracellular membranes were not observed despite extensive searches. Virion-antibody-colloidal gold complexes were, in fact, endocytosed by synchronously infected cells. These complexes were apparently non-infectious, and they accumulated in vacuoles that resembled secondary lysosomes. Exposure of cells to ammonium chloride or to methylamine during the first hour of infection had little inhibitory effect on the production of infectious virus. Chloroquine treatments were inhibitory but this effect depended on relatively late events in the infectious process. The chloroquine inhibitory step blocked infection of virus adsorbed to cells that were exposed to buffers in the $\mathrm{pH}$ range of 4.4 to 8.4. These findings indicate that $\mathrm{BCV}$ penetrates its host cell by direct fusion with the plasmalemma and does not require an acidic intracellular compartment for infectious entry.

\section{Introduction}

Bovine coronavirus (BCV) is a member of the family Coronaviridae of enveloped RNA viruses [31]. The BCV isolates studied in some detail agglutinate erythrocytes of rodents and thus belong to the hemagglutinating coronaviruses. Uniquely, the envelope of these coronaviruses has three glycoproteins. The peplomers consist of the E1 membrane glycoprotein with a molecular mass of $24-26 \mathrm{kDa}$, the E2 glycoprotein with a molecular mass of $100-110 \mathrm{kDa}$ which has cell fusion functions after cleavage from $185 \mathrm{kDa}$ precursor [34] and the E3 hemagglutinin with a molecular mass of $65 \mathrm{kDa}$ or its dimer of $126 \mathrm{kDa}$. Acetylesterase activity is associated with this hemagglutinin [38]. BCV replicates 
in absorptive epithelial cells of the intestinal tract in neonatal calves and induces serious enteric disease [11]. Although many features of coronavirus replication in cultured cells were described $[10,30,32]$, the early events of $\mathrm{BCV}$ infection remain poorly characterized.

At least, two distinct pathways evidently operate for the entry of enveloped viruses into animal cells [15]. Some viruses penetrate the cell by direct fusion of the viral envelope with the plasma membrane. Paramyxoviruses, for example, fuse directly with the cellular plasma membrane under physiological conditions [28]. Other viruses fuse with plasma membranes only at a nonphysiological, low $\mathrm{pH}$ level $[7,8,20,40]$. The second pathway for enveloped virus entry involves cellular uptake by endocytosis $[8,17-20]$. The endocytosed virions travel to membrane bound intracellular compartments where acidic conditions are maintained $[25,37]$. The low $\mathrm{pH}$ of this cellular compartment apparently facilitates fusion between the viral envelope and the vesicle membrane and results in release of the nucleocapsid into the cytoplasm. Infection of cultured cells by a variety of enveloped viruses can be blocked with lysosomotropic weak bases $[8,9,12,14,18,20,22,24]$. These bases accumulate in cells and alter the $\mathrm{pH}$ of acidic cellular compartments $[21,25]$. This change apparently prevents low $\mathrm{pH}$-dependent viral envelope fusion with the vesicle membrane and thus blocks infection [9].

Studies of inhibition by lysosomotropic agents indicate an endocytic mechanism for the entry of mouse coronavirus $[14,16,22,36]$, but the validity of this approach has recently been questioned [2]. Low $\mathrm{pH}$ conditions may not be required for $\mathrm{BCV}$ entry because cells infected with this virus fuse under slighly basic $\mathrm{pH}$ conditions [27]. In order to establish the route of entry for $\mathrm{BCV}$, we examined the early events of the infection process by using lysosomotropic weak bases and colloidal gold mediated immunoelectron microscopy.

\section{Materials and methods}

\section{Cells and virus}

Monolayers of the human rectal tumor cell line HRT-18 [35] were grown in the Dulbecco modification of Eagle medium (DMEM) supplemented with $5 \%$ fetal calf serum. The Mebus strain L9 of bovine coronavirus [29] was propagated in HRT-18 cells. Virus stocks were prepared in cells infected at a multiplicity of approximately 0,01 PFU per cell, incubated for 4 to 5 days at $37^{\circ} \mathrm{C}$ in serum-free DMEM and harvested by freeze-thawing. Viral titers obtained in these preparations ranged from $10^{6}$ to $10^{7} \mathrm{PFU}$ per $\mathrm{ml}$.

\section{Plaque assays}

The infectivity titer was assayed in HRT-18 monolayers grown in 6-well plates. The monolayers were adsorbed with virus for $1 \mathrm{~h}$ at $37^{\circ} \mathrm{C}$, overlayed with serum-free DMEM containing $0.6 \%$ agarose and $4 \mu \mathrm{g}$ of trypsin (Difco Laboratories, Detroit, Mich.) per ml. After 3 days of incubation at $37^{\circ} \mathrm{C}$, plaques were counted without staining. 


\section{Virus purification and concentration}

Infected cultures were harvested at $4 \mathrm{~d}$ post infection when more than $50 \%$ of the cells evidenced cytopathic changes. The infected material was subjected to two freeze-thaw cycles and disrupted by sonication (Sonifier 200; Branson Sonic Power Co., Danbury, Conn.) for $30 \mathrm{sec}$ on ice to release the virus. The virus suspension was clarified by centrifugation at $10,000 \times \mathrm{g}$ for $40 \mathrm{~min}$, sedimented at $90,000 \times \mathrm{g}$ for $2 \mathrm{~h}$ through a $20 \%$ sucrose cushion, and resuspended in DMEM (pH 7.4) buffered with $12 \mathrm{mM} \mathrm{N}$-2-hydroxyethylpiperazine$\mathrm{N}^{\prime}$-2-ethanesulfonic acid (HEPES) and $25 \mathrm{mM} \mathrm{NaHCO}_{3}$ (uptake medium). The recovery of infectious virus ranged from 50 to $75 \%$.

\section{Immunoreagents}

We used a polyclonal rabbit antibody against $\mathrm{BCV}$ particles purified from infected bovine fetal kidney cells. The IgG fraction was obtained by protein-A sepharose column chromatography and was diluted in uptake medium to a level producing less than a $50 \%$ reduction of virus infectivity as determined by a plaque neutralization test. Goat anti-rabbit antibody (IgG) complexed to 5-nm colloidal gold particles (SP Supplies, West Chester, Penn.) was used to probe for antibody binding sites in immunocytochemical investigations.

\section{Immunogold labelling of virus entry}

Cell monolayers, grown in 2-well chamber slides, were rinsed with uptake medium, chilled to $4{ }^{\circ} \mathrm{C}$, and reacted with purified virus for $60 \mathrm{~min}$ at a multiplicity of $50 \mathrm{PFU}$ per cell. The virus-cell complexes were incubated on ice for $45 \mathrm{~min}$ with rabbit anti-BCV antibody, washed twice with uptake medium, and incubated for $45 \mathrm{~min}$ with the antibody-colloidal gold probe. After washing at $4^{\circ} \mathrm{C}$, the cells were rapidly warmed to $37^{\circ} \mathrm{C}$ and incubated for various lengths of time before primary fixation at $4{ }^{\circ} \mathrm{C}$ with $2 \%$ glutaraldehyde and $2 \%$ formaldehyde in $0.1 \mathrm{M}$ sodium cacodylate buffer at $\mathrm{pH} 7.4$.

\section{Processing for electron microscopy}

The aldehyde-fixed monolayers were post-fixed for $1 \mathrm{~h}$ at $25^{\circ} \mathrm{C}$ in a solution of $1 \%$ osmium tetroxide in the presence of $1 \%$ potassium ferrocyanide in $0.1 \mathrm{M}$ cacodylate buffer ( $\mathrm{pH} 7.4$ ), dehydrated in a series of alcohols, and embedded in situ in a mixture of Epon and Araldite epoxy resins [23]. Thin sections were stained with uranyl magnesium acetate and lead citrate and viewed with a Zeiss EM-10 electron microscope at $80 \mathrm{kV}$.

\section{Effects of lysosomotropic bases on BCV infection}

Monolayers of HRT-18 cells were grown in 24-well plates for experiments involving treatments with lysosomotropic agents. The yields of infectious virus were determined by plaque assays after $20 \mathrm{~h}$ of infection at $37^{\circ} \mathrm{C}$.

Infection of HRT-18 cells was synchronized by temperature shift to analyze the relative effects of chloroquine, ammonium chloride, methylamine, and amantadine. Monolayers were washed with medium, chilled to $4^{\circ} \mathrm{C}$, adsorbed for $60 \mathrm{~min}$ with $\mathrm{BCV}$ at a multiplicity of approximately $3 \mathrm{PFU}$ per cell, and rinsed with cold uptake medium to remove unadsorbed virus. The monolayers were given warm medium with the appropriate lysosomotropic bases and transferred to a $37^{\circ} \mathrm{C}$ incubator. In control monolayers, exposure to the base was delayed until $1 \mathrm{~h}$ post infection.

The effects of various concentrations of ammonium chloride and chloroquine in virus infection at $37^{\circ} \mathrm{C}$ were tested on monolayers that were washed with uptake medium and pretreated for $15 \mathrm{~min}$ with the base diluted in uptake medium. The cells were infected with $\mathrm{BCV}$ at $37^{\circ} \mathrm{C}$ for $60 \mathrm{~min}$ at a multiplicity of approximately $3 \mathrm{PFU}$ per cell and then given 
fresh uptake medium containing the base. Exposure to the lysosomotropic agent was delayed until $1 \mathrm{~h}$ post infection in control monolayers.

The time dependence of inhibition by $120 \mu \mathrm{M}$ chloroquine was analyzed by measuring the effects of increasing delays in chloroquine addition. The monolayers were synchronously infected as described above except that chloroquine was first added to the cultures at various times after rewarming.

The $\mathrm{pH}$ dependence of chloroquine inhibition was determined with monolayers that were allowed to bind $\mathrm{BCV}$ at $4^{\circ} \mathrm{C}$ and then were washed with cold DMEM. The cells were warmed to $37^{\circ} \mathrm{C}$ for $60 \mathrm{sec}$ by the addition of DMEM buffered with $12 \mathrm{mM}$ HEPES and $12 \mathrm{mM}$ 2-(N-morpholino-)ethanesulfonic acid (MES) at various pH levels and given fresh uptake medium with $120 \mu \mathrm{M}$ chloroquine. Chloroquine was added at $1 \mathrm{~h}$ post infection for a final concentration of $120 \mu \mathrm{M}$ in all monolayers.

\section{Indirect immunofluorescence}

Monolayers were fixed for $10 \mathrm{~min}$ in $4 \%$ formaldehyde, permeabilized for $5 \mathrm{~min}$ with acetone at $-20^{\circ} \mathrm{C}$, incubated with rabbit anti-BCV antibody, and reacted with goat anti-rabbit antibody conjugated to fluorescein isothiocyanate. The preparations were viewed with a Leitz fluorescent microscope and each field was photographed using both epifluorescence and phase contrast optics. The percentage of fluorescent cells in each preparation was calculated from 5 randomly selected fields of approximately 200 cells each.

\section{Chemicals}

Stock solutions were prepared daily of $20 \mathrm{mM}$ chloroquine- $\mathrm{HCl}, 200 \mathrm{mM}$ amantadine- $\mathrm{HCl}$, 1.0 M ammonium chloride, and 4.0 M methylamine (Sigma Chemical Co., St. Louis, Mo.) in saline. The solutions were adjusted to neutral $\mathrm{pH}$ with $\mathrm{NaOH}$, and diluted into uptake medium.

\section{Results}

\section{Morphologic analysis of $B C V$ adsorption}

Thin section of cells adsorbed with BCV particles and immunolabeled at $4{ }^{\circ} \mathrm{C}$ revealed that coated pit formation had ceased leaving all virions at the cell exterior (Fig. 1). The virions were readily identified by the associated colloidal gold particles. The use of highly dilute anti-BCV antibody labeled most virions with only a few gold particles. These particles were separated from the viral envelope by an average distance of about $15 \mathrm{~nm}$. The virus particles usually contained an electron-dense core and were spherical in shape with diameters ranging from 50 to $80 \mathrm{~nm}$. Virions with ellipsoidal profiles also were observed. The viral envelope was separated from the plasma membrane by a distance of less than $15 \mathrm{~nm}$ in many cases. Fibrillar connections were evident at the plasma membrane attachment site (Fig. 1, inset) but the peplomer structures of $\mathrm{BCV}$, distinctive in negative stains, could rarely be distinguished. The virus particles were unevenly distributed among the cells. Most cells in individual thin section were free of virus particles or were associated with only one or two virions. Other cells were observed with as many as 25 virions along the apical cell surface in a single thin section. This distribution infers that virus particles were adsorbed by only a subpopulation of HRT-18 cells in the monolayer. 


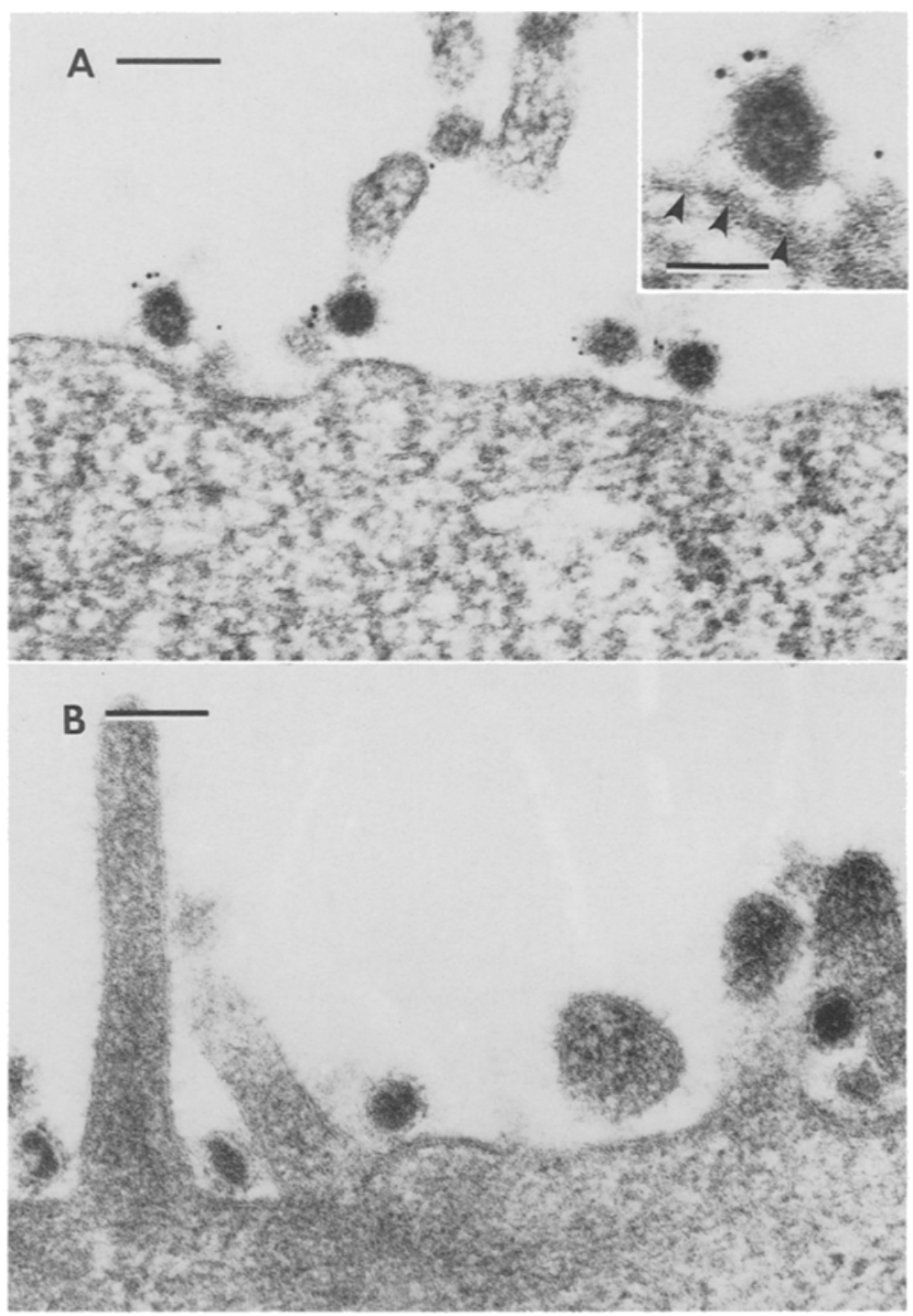

Fig. 1. Immunoelectron microscopic analysis of $\mathrm{BCV}$ interaction with the plasma membrane at $4^{\circ} \mathrm{C}$. A Virus particles are labeled with gold. Envelope projections contact the cell membrane (inset, arrowheads). B Gold particles fail to bind with virions in preparations incubated with normal rabbit serum IgG. Bars: $100 \mathrm{~nm}$, inset bar: $50 \mathrm{~nm}$

\section{Endocytosis of $B C V$ at $37^{\circ} \mathrm{C}$}

Virus particles at intracellular locations were morphologically less readily distinguished, but the associated gold label permitted identification of intracellular $\mathrm{BCV}$ particles during uptake. After the BCV-cell complexes were incubated for 2 to $5 \mathrm{~min}$ at $37^{\circ} \mathrm{C}$, labeled $\mathrm{BCV}$ particles were evident in coated vesicles and in small multiform vesicles with smooth membranes (Fig. 2).

Coated vesicles had circular profiles of $100 \mathrm{~nm}$ in diameter, whereas the smooth membrane vesicles were typically larger (160 to $300 \mathrm{~nm}$ in the greater 


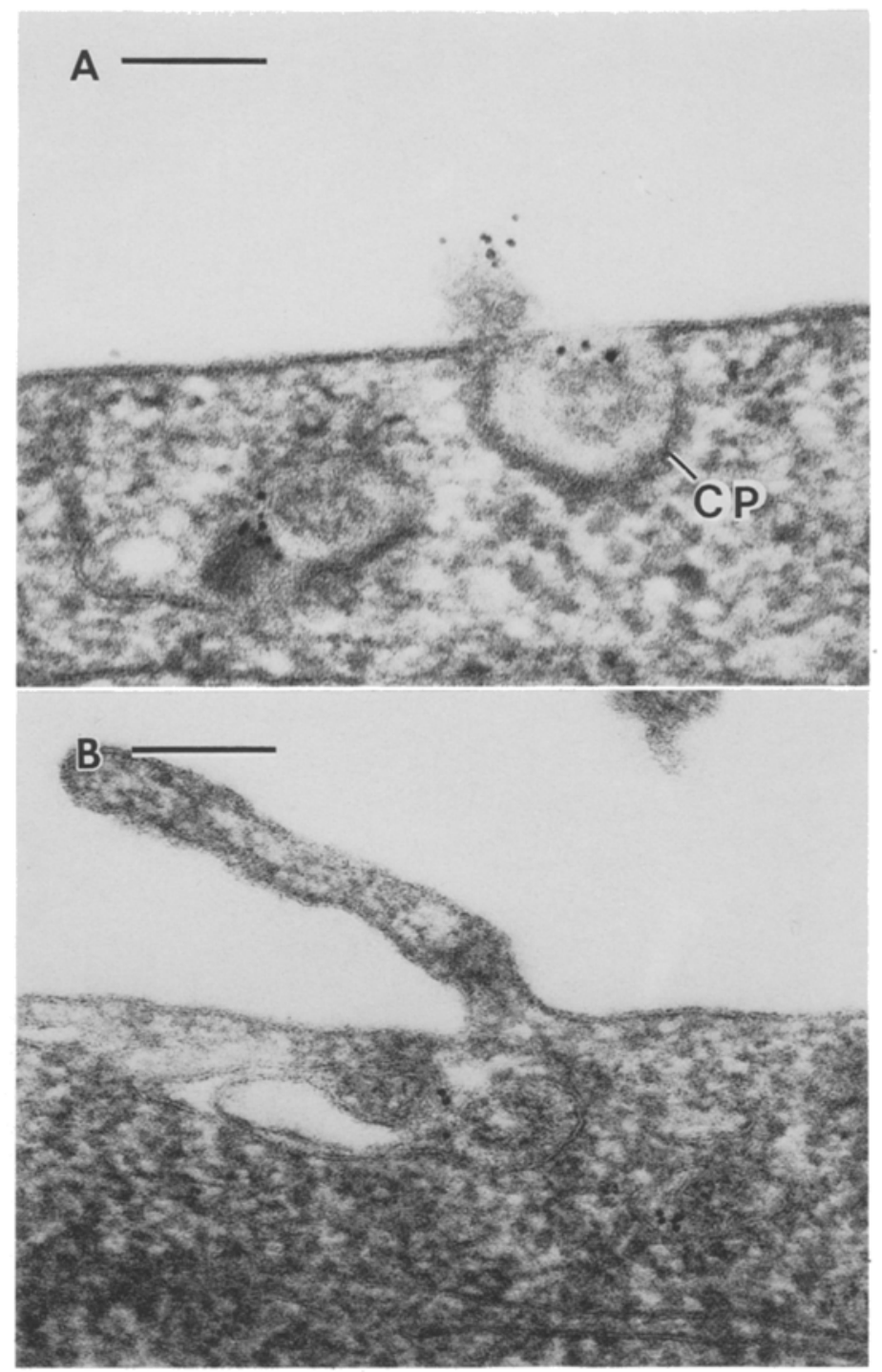

Fig. 2. Early stages of BVC internalization. Monolayers were warmed for 2 min (A) or $5 \mathrm{~min}(\mathrm{~B})$. Immunogold labeled virus particles are found in a coated pit $(C P)$. Bars: $100 \mathrm{~nm}$

dimension) and had diversely shaped profiles. These membranous compartments contained only one or two virus particles but had very little empty space and few nonviral content. After 10 to 15 min incubation at $37^{\circ} \mathrm{C}$, the intracellular virions accumulated in larger vacuoles, 400 to $800 \mathrm{~nm}$ across (Fig. 3). These vacuoles contained as many as 10 labeled virus particles which appeared to be partially degraded. The large vacuoles also contained unlabeled vesicles, fibrillar strands, and amorphous material, features of secondary lysosomes.

Gold particles were closely associated with virus structures and were separated from the nearest limiting cellular membrane by distances exceeding $20 \mathrm{~nm}$. 

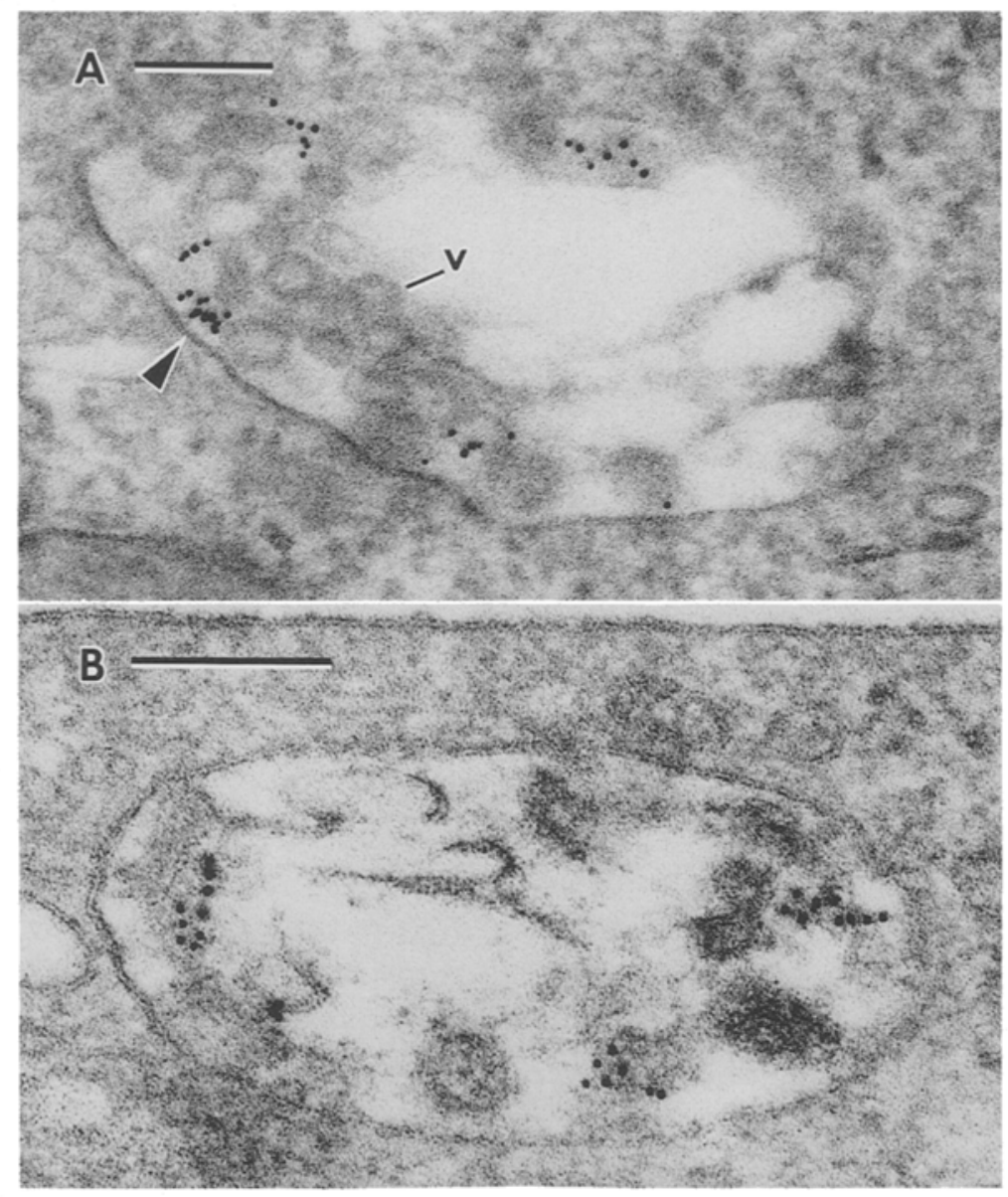

Fig. 3. Accumulation of $\mathrm{BCV}$ inside vacuoles. Virus-cell complexes were incubated for $10 \mathrm{~min}(\mathrm{~A})$ or $15 \mathrm{~min}(\mathrm{~B})$ at $37^{\circ} \mathrm{C}$. Electron dense particles associated with gold represent partially degraded virions. Vacuole contents also include unlabeled vesicles (v) and fibrillar debris. Note possible site of gold association with vacuole membrane (4). Bars: $100 \mathrm{~nm}$

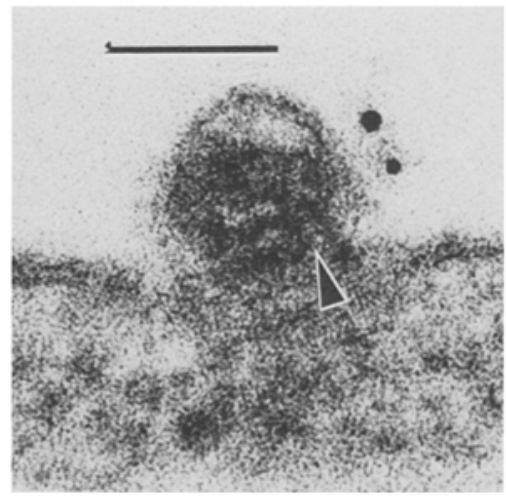

Fig. 4. Interaction of $\mathrm{BCV}$ envelope with plasma membrane. Virus cell complexes were rewarmed for $30 \mathrm{sec}$. Site of apparent fusion. Bar: $50 \mathrm{~nm}$ 
Associations between gold particles and vesicle membranes were rarely seen (Fig. 3). After rewarming, gold particles were observed at plasma membrane sites distant from adsorbed virions. Apparent fusion of the virus envelope with the plasma membrane was recorded (Fig. 4), but fusion of gold-labeled virions with intracellular membranes was never observed. Cells with surface-adsorbed virus that were incubated with normal rabbit IgG instead of anti-BCV antibody were not labeled by the gold probe (Fig. 1B).

Furthermore, few gold particles were observed at plasma membrane sites in the absence of virus particles when virus-cell complexes were immunolabeled and fixed at $4{ }^{\circ} \mathrm{C}$. These controls indicated that the immunoreagents specifically marked BCV antigens and not HRT-18 cell membranes.

\section{Effect of lysosomotropic agents on the yield of infectious virus}

To compare the effect of bases, synchronously infected cells were treated with chloroquine, amantadine, ammonium chloride or methylamine (Table 1) at concentrations previously found to be effective in studies of virus entry $[8,12,20$, 24]. Treatment with a given base was continued until virus harvest. Virus yields were reduced to some extent by each of the inhibitors. The degree of the reduction by each inhibitor depended on the duration of the treatment period. We measured virus yields of cultures treated from the time of infection and compared these values to yields in cultures first exposed to the inhibitor at $1 \mathrm{~h}$ post infection. The latter value provided a baseline from which we could evaluate the effects of the inhibitor during the first hour of infection.

Virus yields were suppressed to approximately $25 \%$ when $10 \mathrm{mM}$ ammonium chloride or $10 \mathrm{mM}$ methylamine was added at $1 \mathrm{~h}$ post infection. The presence of these bases during the first hour of infection reduced $\mathrm{BCV}$ yields by 34 to $37 \%$. Amantadine was a stronger inhibitor of virus yield but this inhibitory effect was also seen in control preparations. Thus, only chloroquine suppressed $\mathrm{BCV}$ replication during the first hour of infection. Infected cells that were exposed to $120 \mu \mathrm{M}$ chloroquine from the time of synchronous infection until

Table 1. Effect of lysosomotropic agents on BCV infection

\begin{tabular}{llll}
\hline Inhibitor (mM conc) & \multicolumn{2}{l}{ Virus yield $^{\mathrm{a}}$} & \\
\cline { 2 - 4 } & full exposure & delayed exposure & \% reduction \\
& & \\
\hline Ammonium chloride (10) & $15(7.02)$ & $23(7.20)$ & 34 \\
Methylamine (10) & $15(6.53)$ & $24(6.73)$ & 37 \\
Amantadine (0.5) & $5.5(6.09)$ & $7.0(5.90)$ & 22 \\
Chloroquine (0.12) & $0.1(3.87)$ & $6.5(5.72)$ & 99 \\
\hline
\end{tabular}

${ }^{a}$ Virus yield listed as percent of positive control and as log PFU per $\mathrm{ml}$ (in parentheses)

${ }^{b}$ Percent reduction calculated as (1.0-[full exposure/delayed exposure $\left.]\right)$ 

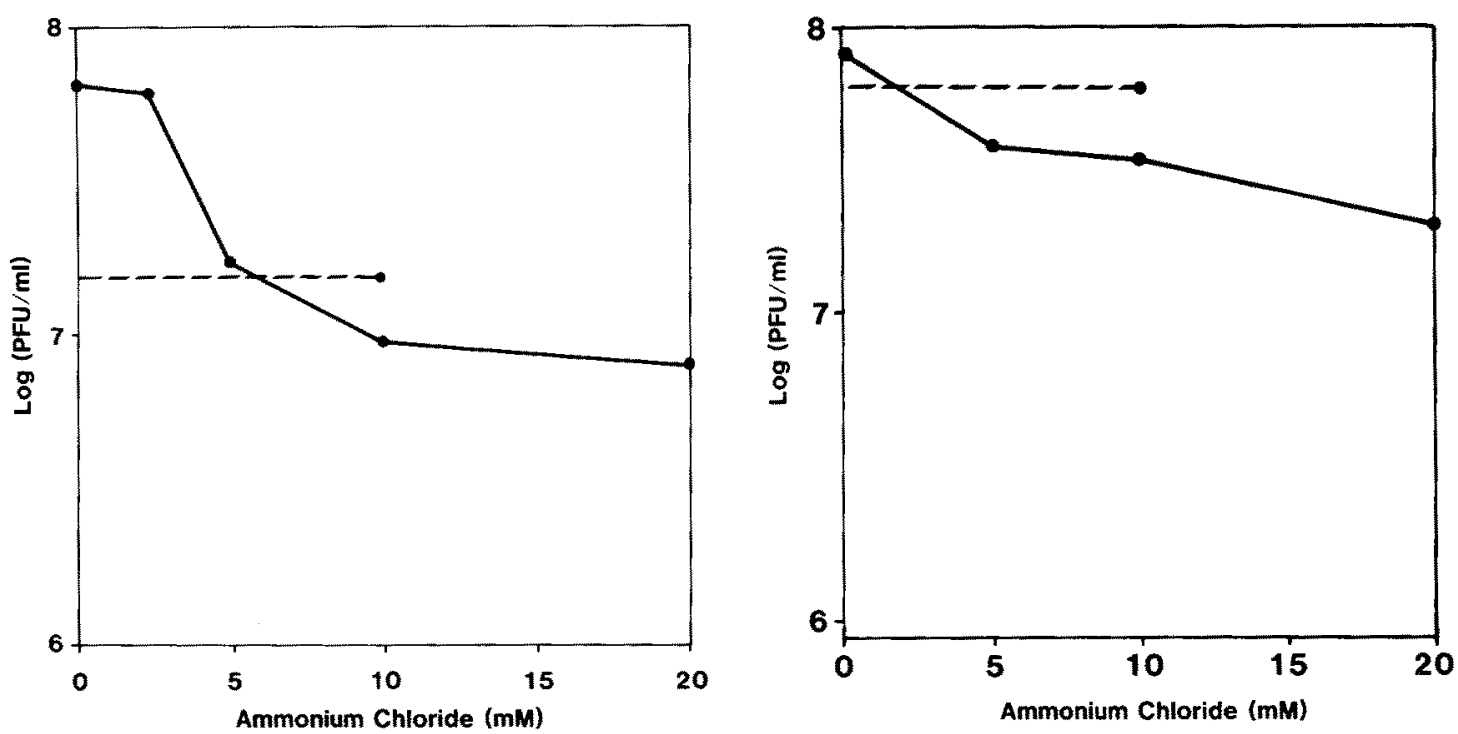

Fig. 5

Fig. 6
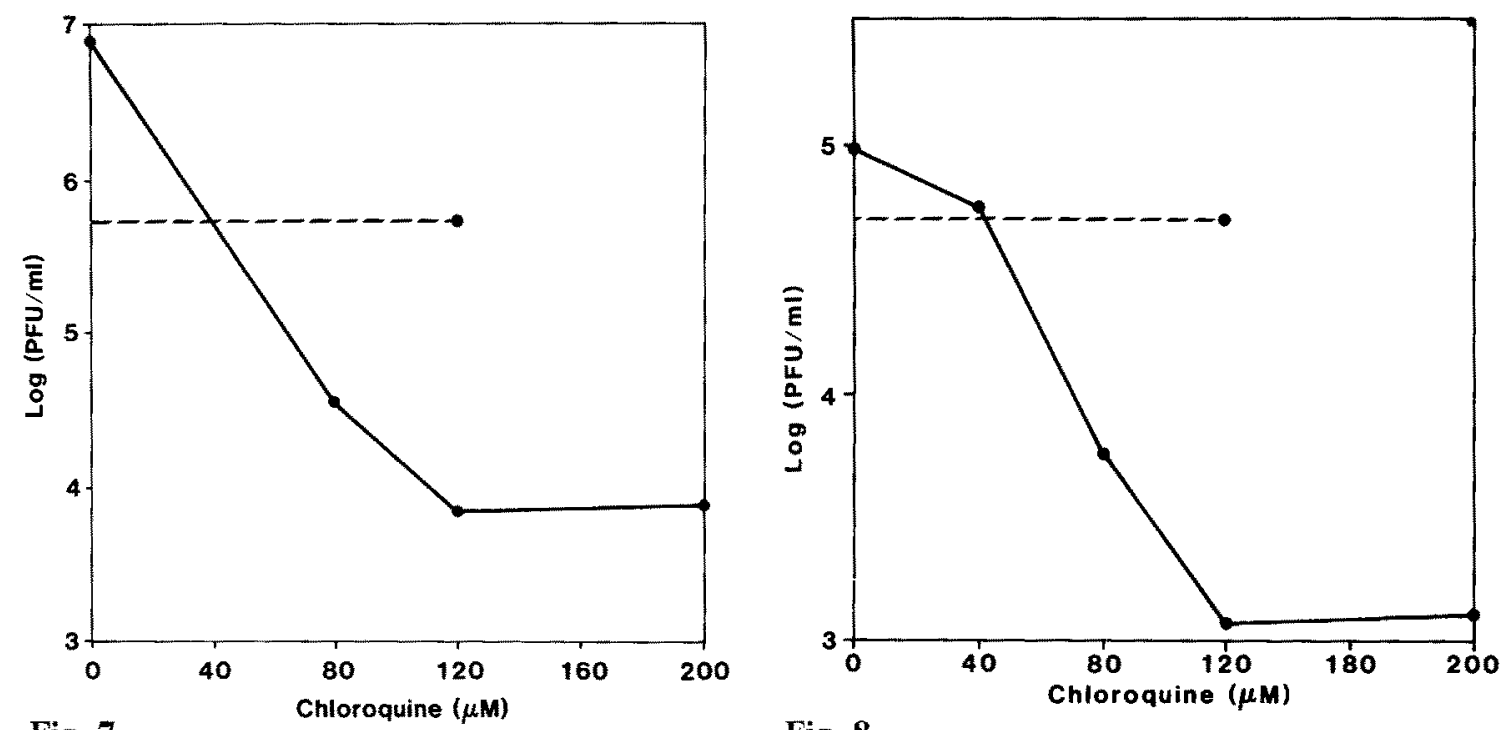

Fig. 8

Fig. 5. Effect of ammonium chloride on virus yield by infected HRT-18 cells synchronously infected with BCV. Dashed line represents virus level when $10 \mathrm{mM}$ ammonium chloride was added at $1 \mathrm{~h}$ post infection

Fig. 6. Effect of ammonium chloride on virus yield by HRT-18 cells infected by BCV at $37^{\circ} \mathrm{C}$. Dashed line represents virus level when $10 \mathrm{mM}$ ammonium chloride was added at $1 \mathrm{~h}$ post infection

Fig. 7. Effect of chloroquine on virus yield by synchronously infected cells. Dashed line represents virus level when $120 \mu \mathrm{M}$ chloroquine was added at $1 \mathrm{~h}$ post infection

Fig. 8. Effect of chloroquine on virus yield by HRT-18 cells infected at $37^{\circ} \mathrm{C}$. Dashed line represents virus level when $120 \mu \mathrm{M}$ chloroquine was added at $1 \mathrm{~h}$ post infection 
harvest produced only $1.4 \%$ as much virus as did cultures treated with chloroquine $1 \mathrm{~h}$ post infection.

Synchronously BCV infected monolayers were exposed to various doses of ammonium chloride and chloroquine at the time of temperature shift to avoid drug effects on the virus adsorption stage. A second set of monolayers was pretreated with the drugs for $15 \mathrm{~min}$ and infected at $37^{\circ} \mathrm{C}$ to ensure that intravacuolar $\mathrm{pH}$ levels were altered. The effects of the agents were similar for both infection protocols. Ammonium chloride reduced the yield of BCV in synchronously infected cells by less than $1 \mathrm{log}$-unit even at $20 \mathrm{mM}$ levels (Fig. 5). A similar unresponsiveness to ammonium chloride treatment occurred during infection at $37^{\circ} \mathrm{C}$. Pretreatment with $10 \mathrm{mM}$ ammonium chloride decreased BCV by $37 \%$ from levels produced when the agent was added after a $1 \mathrm{~h}$ delay (Fig. 6). Synchronous infection was strongly inhibited by 80 to $200 \mu \mathrm{M}$ chloroquine (Fig. 7). Cells pretreated with this base and infected at $37^{\circ} \mathrm{C}$ also produced less virus with increasing concentrations of the inhibitor (Fig. 8). Exposure to chloroquine at the $120 \mu \mathrm{M}$ level resulted in the optimal reduction in virus yield. Concentrations of the drug higher than $200 \mu \mathrm{M}$ diminished total virus yield in $1 \mathrm{~h}$ delay treatments to levels obtained by pretreatment. The inhibitory effect of $120 \mu \mathrm{M}$ chloroquine on the early stages of BCV replication was therefore examined more closely in subsequent experiments.

\section{Chloroquine inhibition of viral antigen production in infected cells}

Immunofluorescence studies revealed that chloroquine treatments affected the number of BCV-infected cells in HRT-18 monolayers (Table 2). Treatments of synchronously infected cultures decreased the number of fluorescent, antigen producing cells at 12 to $36 \mathrm{~h}$ post infection. Replication of BCV occurred in 10 to $17 \%$ of the cell population in untreated cultures. Only $1 \%$ or less of the cell population produced BCV antigens when exposed to chloroquine at the time of infection. The numbers of fluorescent cells in the monolayers reached nearly normal levels when this treatment was delayed for $1 \mathrm{~h}$ even though cells vacuolization was pronounced.

Table 2. Chloroquine inhibition of antigen production

\begin{tabular}{lcrr}
\hline \multirow{2}{*}{ Drug exposure } & \multicolumn{3}{c}{$\%$ Fluorescing cells } \\
& $12 \mathrm{~h}$ & $18 \mathrm{~h}$ & $36 \mathrm{~h}$ \\
\hline None & 10 & 17 & 10 \\
Full & 1 & 0 & 1 \\
Delayed & 9 & 5 & 11 \\
\hline
\end{tabular}

${ }^{a}$ Fluorescent cell population expressed as percent of total at indicated times post infection 
Time dependence of sensitivity to chloroquine inhibition

Chloroquine treatment was initiated at various times after synchronous infection (Fig. 9). Virus yields remained at low levels in cultures that were initially exposed to the drug at $5 \mathrm{~min}$ or less. When exposure to chloroquine was delayed until 10 min post infection, virus yield was suppressed by more than $75 \%$. Inhibition at $50 \%$ of maximum occurred with a treatment delay of approximately $15 \mathrm{~min}$. These results show that 5 to $10 \mathrm{~min}$ are required for infection to proceed beyond the chloroquine sensitive step in the very early stages of $\mathrm{BCV}$ replication. Electron microscopy revealed $\mathrm{BCV}$ particles progressing from the endosome to the lysosomes during this period.

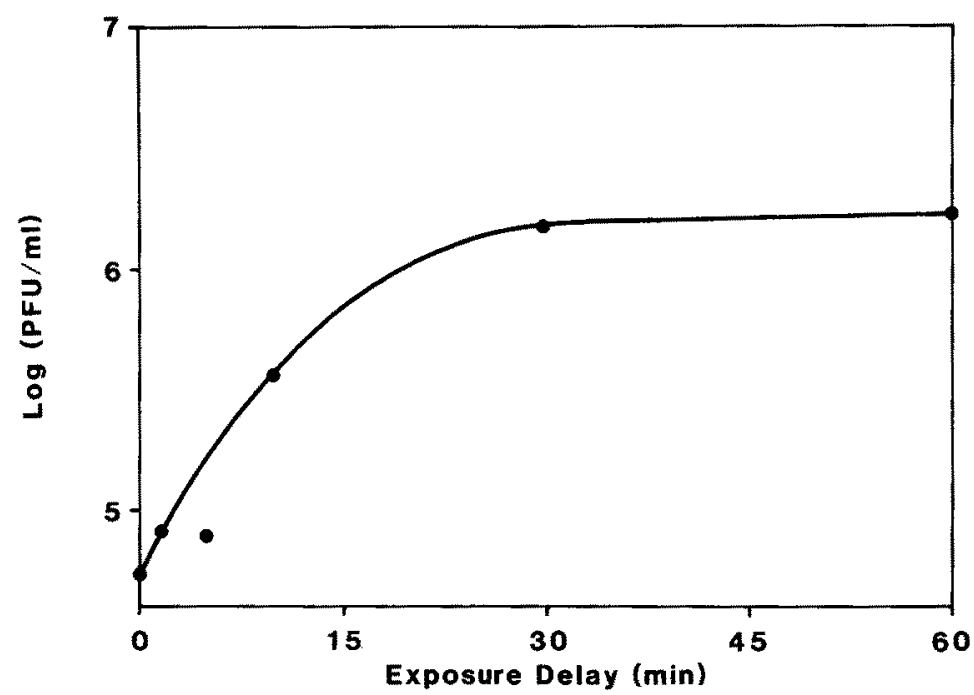

Fig. 9. Time dependence of chloroquine inhibition of $\mathrm{BCV}$ infection

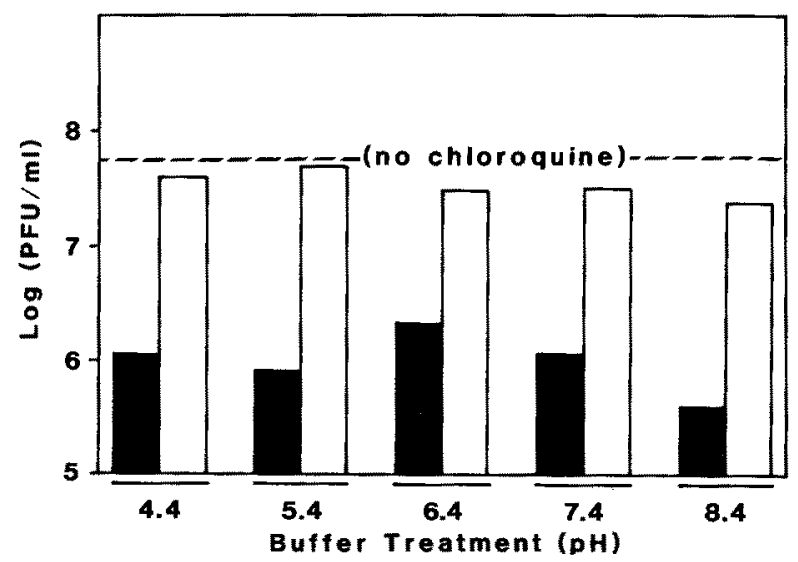

Fig. 10. Independence of chloroquine inhibition to $\mathrm{pH}$ treatments. Cultures were exposed to chloroquine before the buffer treatment $(\square)$ or after a delay of $1 \mathrm{~h}$ 


\section{Independence of chloroquine inhibition to $\mathrm{pH}$ treatments}

In an attempt to overcome the chloroquine imposed block in BCV entry, we provided conditions conducive to fusion between the plasma membrane and envelopes of infecting virions. Monolayers with virus adsorbed at $4^{\circ} \mathrm{C}$ were exposed to chloroquine and briefly treated with warm buffers at various $\mathrm{pH}$ levels to simulate conditions in intracellular vacuoles. We found that chloroquine was an effective inhibitor of $\mathrm{BCV}$ infection despite buffer treatments in the $\mathrm{pH}$ range of 4.4 to 8.4 (Fig. 10).

\section{Discussion}

Recent investigations have re-examined the role of endocytosis in infections by several animal viruses. Morphologic analyses have generally indicated that coronaviral entry is accomplished by endocytosis $[3-5,13,26]$; yet other investigations suggested that coronaviruses enter the cell by direct fusion with the plasma membrane $[6,27]$. One of the objectives of our study was to employ immunolocalization to investigate the entry pathway for BCV.

Electron microscopic analysis revealed fusion of the viral envelope with the plasma membrane and confirmed that BCV particles were endocytosed by HRT18 cells. Shortly after warming, virus particles were seen in coated pits and in small endocytic vesicles with smooth membranes. Viral particles accumulated later in structures with features of secondary lysosomes. These endocytic events resemble superficially an alternative mode for infectious entry of BCV. Goldlabeling of BCV particles was mediated by highly diluted neutralizing antibodies which did not reduce infectivity to a measurable extent. Some of the labeled virions probably represent non-infectious virus antibody-gold complexes. Their endocytosis would lead to sequestration in lysosomal compartments. However, this event appears to be irrelevant to infectious entry of BCV because we were never able to find clear morphologic evidence of fusion events along the intracellular membranes. This implies that $\mathrm{BCV}$ effects infectious entry by direct fusion at the cell surface.

Experiments with lysosomotropic weak bases were conducted to assess the requirement for an acidic compartment during $\mathrm{BCV}$ infectious entry. Our results virtually failed to reveal an unequivocal involvement of an acidic compartment. Ammonium chloride and methylamine, which raise the $\mathrm{pH}$ of endocytic vesicles [21], were not inhibitory for events in the first hour of BCV replication. Endocytosed viral particles reached lysosomes as early as 10 min after infection but fusion with their membrane was not observed. Although amantadine treatment from the time of infection reduced virus yield, this base was also toxic when added after a 60 -min delay.

Chloroquine interfered with a relatively early stage of $\mathrm{BCV}$ replication as determined by the yield of infectious virus and by the number of BCV-infected cells. This effect apparently did not involve inhibition of viral envelope fusion with cell membranes. Besides raising the $\mathrm{pH}$ of lysosomes, chloroquine exerts 
other effects on cellular functions, including inhibition of viral RNA synthesis [2]. These effects may be responsible for the $6.5 \%$ drop in $\mathrm{BCV}$ production when the drug is added $1 \mathrm{~h}$ after rewarming. We probed the chloroquine sensitivity during the very early stages of BCV infection. The kinetics of time dependence for chloroquine inhibition lead us to conclude that a sensitive step in BCV replication occurs after $5 \mathrm{~min}$ of infection (Fig. 9). Addition of chloroquine as late as $10 \mathrm{~min}$ after rewarming inhibits replication substantially [75].

In contrast, infection with Semliki Forest virus (SFV), which enters the cell by the endocytic pathway, reaches the chloroquine insensitive phase within $4 \mathrm{~min}$, and later treatments with the base are relatively ineffective $[8,39,40]$. Brief treatment of SFV-adsorbed cell cultures with low $\mathrm{pH}$ media lifted the chloroquine block apparently by inducing virus fusion at the plasma membrane $[8,39]$. The chloroquine-blocked step in $\mathrm{BCV}$ infection was essentially unaffected by $\mathrm{pH}$ treatments in the range of 4.4 to 8.4 . This failure to relieve the chloroquine block in $\mathrm{BCV}$ replication would be expected if plasma membrane fusion with $\mathrm{BCV}$ is not triggered by low $\mathrm{pH}$ treatments. This finding is in harmony with $\mathrm{BCV}$-induced cell fusion in infected bovine fetal spleen cells which fused optimally at a slightly basic $\mathrm{pH}[27]$, similar to a murine coronavirus-host cell system [33]. An alternative explanation for a continued chloroquine block despite low $\mathrm{pH}$ treatment is inhibition of events in replication subsequent to fusion. Investigators of Sindbis virus infection concluded that chloroquine inhibits only postfusion events in the replication of this virus [2]. The inhibitory activity was attributed to an effect on viral RNA synthesis rather than a block in Sindbis virus entry into the cell.

Our data indicate that BCV infection does not involve the endocytic route. Endocytosis of this virus appears to represent an abortive infection with subsequent virus degradation in lysosomes. The virions that were endocytosed were not observed to fuse with the vesicle membrane. Instead, the particles accumulated in a somewhat degraded form in lysosome-like structures. Furthermore, a low $\mathrm{pH}$ compartment is apparently unnecessary for $\mathrm{BCV}$ infection and virusinduced membrane fusion seems to be an event independent of low $\mathrm{pH}$ treatments. These features suggest that $\mathrm{BCV}$ infects cells by direct fusion with the plasma membrane. Doughri et al. [6] observed interactions of BCV strain LY138 with the plasmalemma of infected intestinal epithelial cells and asserted that virus uptake had occurred by direct fusion with the plasma membrane. Our studies provide evidence to support that conclusion.

Note added in proof. Recently published reports [33a, 38a] describe characteristics of the mouse coronavirus spike glycoprotein E2 that are consistent with its role in infectionpenetration at the plasma membrane rather than within endocytic vesicles.

\section{Acknowledgements}

This work was supported by grants 80-CRSR-2-0650, 86-CRSR-2-2871, and 89-341164675 from the United States Department of Agriculture. This paper contains parts of a dissertation submitted by H. R. Payne to Louisiana State University in partial fulfillment of the requirements for the $\mathrm{Ph}$. D. degree. 


\section{References}

1. Andersen KB, Nexo BA (1983) Entry of murine retrovirus into mouse fibroblasts. Virology 125: 85-98

2. Cassell S, Edwards J, Brown DT (1984) Effects of lysosomotropic weak bases on infection of BHK-12 cells by Sindbis virus. J Virol 52: 857-864

3. Chasey D, Alexander DJ (1976) Morphogenesis of avian infectious bronchitis virus in primary chick kidney cells. Arch Virol 52: 101-111

4. David-Ferreira JF, Manaker RA (1965) An electron microscope study of the development of a mouse hepatitis virus in tissue culture cells. J Cell Biol 24: 57-78

5. Dimmock NJ (1982) Initial stages in infection with animal virus. J Gen Virol 59: 122

6. Doughri AM, Storz J, Hajer I, Fernando HS (1976) Morphology and morphogenesis of a coronavirus infecting intestinal epithelial cells of newborn calves. Exp Mol Pathol 25: $355-370$

7. Gonzales-Scarano F, Pobjecky N, Nathanson N (1984) La Crosse bunyavirus can mediate $\mathrm{pH}$-dependent fusion from without. Virology 132: 222-225

8. Helenius A, Kartenbeck J, Simons K, Fries E (1980) On the entry of Semliki Forest virus into BHK-21 cells. J Cell Biol 84: 404-420

9. Helenius A, Marsh M, White J (1982) Inhibition of Semliki Forest virus penetration by lysosomotropic weak bases. J Gen Virol 58: 47-61

10. Holmes KV (1985) Replication of coronaviruses. In: Fields BN, Knipe DM, Chanock RN, Melnick J, Roizman B, Shope R (eds) Virology. Raven Press, New York, pp 1331 1343

11. House JA (1978) Economic impact of rotavirus and other neonatal disease agents of animals. J Am Vet Med Assoc 173: 573-576

12. Kielian MC, Keranen S, Kaariainen L, Helenius A (1984) Membrane fusion mutants of Semliki Forest virus. J Cell Biol 98: 139-145

13. Krzystniak K, Dupuy JM (1981) Early interaction between mouse hepatitis virus 3 and cells. J Gen Virol 57: 53-61

14. Krzystniak K, Dupuy JM (1984) Entry of mouse hepatitis virus 3 into cells. J Gen Virol 65: 227-231

15. Lenard J, Miller KD (1982) Uncoating of enveloped viruses. Cell 28: 5-6

16. Mallucci L (1966) Effect of chloroquine on lysosomes and on growth of mouse hepatitis virus (MHV-3). Virology 28: 355-362

17. Marsh M, Helenius A (1980) Adsorptive endocytosis of Semliki Forest virus. J Mol Biol 142: 439-454

18. Marsh M, Bolzau E, Helenius A (1983) Penetration of Semliki Forest virus from acidic prelysosomal vacuoles. Cell 32: 931-940

19. Marsh M, Matlin K, Simons K, Reggio H, White J, Kartenbeck J, Helenius A (1982) Are lysosomes a site of enveloped-virus penetration? Cold Spring Harbor Symp Quant Biol 46: 835-843

20. Matlin KS, Reggio J, Helenius A, Simons K (1981) Entry pathway of influenza virus in a canine kidney cell line. J Cell Biol 91: 601-613

21. Maxfield FR (1982) Weak bases and ionophores rapidly and reversibly raise the pH of endocytic vesicles in cultured mouse fibroblasts. J Cell Biol 95: 676-681

22. Mizzen L, Hilton A, Cheley S, Anderson R (1985) Attenuation of murine coronavirus infection by ammonium chloride. Virology 142: 378-388

23. Mollenhauer HH (1964) Plastic embedding mixtures for use in electron microscopy. Stain Technol 39: 111-114

24. Nemerow GR, Cooper NR (1984) Early events in the infection of human B lymphocytes by Epstein-Barr virus: the internalization process. Virology 132: 186-198 
25. Okhuma S, Poole B (1978) Fluorescence probe measurement of the intralysosomal pH in living cells and the perturbation of $\mathrm{pH}$ by various agents. Proc Natl Acad Sci USA 75: $3327-3331$

26. Patterson S, Bingham RW (1976) Electron microscope observations on the entry of avain infectious bronchitis virus into susceptible cells. Arch Virol 53: 267-273

27. Payne HR, Storz J (1988) Analysis of cell fusion induced by bovine coronavirus infection. Arch Virol 103: 27-33

28. Poste G, Pasternak CA (1978) Virus-induced cell fusion. In: Poste G, Nicholson GL (eds) Cell surface reviews, vol 4. Elsevier/North-Holland, Amsterdam, pp 305-357

29. Sharpee RL, Mebus CA, Bass EP (1976) Characterization of a calf diarrheal coronavirus. Am J Vet Res 37: 1031-1041

30. Siddell SG, Wege H, ter Meulen V (1982) The structure and replication of coronaviruses. Curr Top Microbiol Immunol 99: 131-163

31. Siddell SG, Anderson R, Cavanagh D, Fujiwara K, Klenk HD, Macnaughton MR, Pensaert M, Stohlman SA, Sturman L, van der Zeijst BAM (1983) Coronaviridae. Intervirology 20: 181-189

32. Sturman LS, Holmes KV (1982) The molecular biology of coronaviruses. Adv Virus Res 28: 35-112

33. Sturman LS, Ricard CS, Holmes KV (1985) Proteolytic cleavage of the E2 glycoprotein of murine coronavirus: activation of cell-fusion activity of virions by trypsin and separation of two different $90 \mathrm{k}$ cleavage fragments. J Virol 56: 904-911

33a. Sturman LS, Ricard CS, Holmes KV (1990) Conformational change of the coronavirus peplomer glycoprotein at $\mathrm{pH} 8.0$ and $37^{\circ} \mathrm{C}$ correlates with virus aggregation and virusinduced cell fusion. J Virol 64: 3042-3050

34. St Cyr-Coats K, Storz J, Hussain KA, Schnorr KL (1988) Structural proteins of bovine coronavirus strain L9: effects of the host cells and trypsin treatment. Arch Virol 103: 35-43

35. Tompkins WAF, Watrach AM, Schmale JD, Schultz RM, Harris JA (1974) Cultural and antigenic properties of newly established cell strains from adenocarcinomas of human colon and rectum. J Natl Cancer Inst 52: 101-106

36. Tooze J, Tooze SA (1985) Infection of AtT20 murine pituitary tumour cells by mouse hepatitis virus strain A59: virus budding is restricted to the Golgi region. EMBO J 37: 203-212

37. Tycko B, Maxfield FR (1982) Rapid acidification of endocytic vesicles containing alpha-2-macroglobulin. Cell 28: 643-651

38. Vlasak R, Lnytzes W, Leider, J, Spaan W, Palese P (1988) The E3 protein of bovine coronavirus is a receptor-destroying enzyme with acetylesterase activity. $J$ Virol 62 : $4686-4690$

38a. Weismiller DG, Sturman LS, Buchmeier MJ, Fleming JO, Holmes KV (1990) Monoclonal antibodies to the peplomer glycoprotein of coronavirus mouse hepatitis virus identify two subunits and detect a conformational change in the subunit released under mild alkaline conditions. J Virol 64: 3051-3055

39. White J, Kartenbeck J, Helenius A (1980) Fusion of Semliki forest virus with the plasma membrane can be induced by low pH. J Cell Biol 87: 264-272

40. White J, Matlin K, Helenius A (1981) Cell fusion by Semliki Forest, influenza, and vesicular stomatitis viruses. J Cell Biol 89: 674-679

Autors' address: H. R. Payne, Department of Neurosciences, Case Western Reseve University, Cleveland, $\mathrm{OH} 44106$, U.S.A. 